\title{
Perancangan Sistem Informasi Penjualan Pakaian Berbasis Web Pada Toko Uj Outlet
}

\author{
Moh Afdhol Rizal ${ }^{[1]}$, Titik Misriati ${ }^{[2]}$ \\ AMIK BSI Bekasi, Jalan Cut Mutiah No 88 Bekasi $^{[1]}$, \\ AMIK BSI Jakarta, Jl. R.S Fatmawati No. 24 Jakarta Selatan ${ }^{[2]}$ \\ mohafdho1002@bsi.ac.id ${ }^{[1]}$, titik.tmi@bsi.ac.id ${ }^{[2]}$
}

\begin{abstract}
Abstrak-Toko Uj Outlet adalah toko yang menjual berbagai jenis pakaian pria bermerek buatan lokal dengan kualitas ekspor. Pakaian bermerek yang dijual di Toko Uj Outlet antara lain celana, kemeja, dan jaket. Promosi yang dilakukan oleh Toko Uj Outlet masih kurang memadai sehingga masih banyak masyarakat yang belum mengetahui keberadaan Toko Uj Outlet. Selain itu, penjualan pada Toko Uj Outlet hanya dilakukan secara konvensional dimana konsumen harus datang langsung ke Toko Uj Outlet untuk membeli pakaian. Oleh sebab itu, penelitian ini dilakukan untuk merancang sebuah website penjualan pada Toko Uj Outlet agar dapat mempromosikan pakaian yang dijual secara luas dan mempermudah konsumen dalam melakukan pembelian tanpa harus datang langsung ke Toko Uj Outlet.
\end{abstract}

Kata Kunci: Penjualan, E-commerce, Uj Outlet, Pakaian

\section{PENDAHULUAN}

Penjualan merupakan suatu fungsi dari pemasaran yang sangat penting dan menentukan bagi perusahaan untuk mencapai tujuan dari perusahaan tersebut yaitu memperoleh laba untuk kelangsungan hidup dari perusahaan tersebut [1].

Toko Uj Outlet adalah toko yang menjual berbagai macam pakaian branded pria. Toko Uj Outlet jadi satu-satunya yang menjual pakaian branded buatan lokal dengan kualitas ekspor, salah satu Mall di Jakarta Selatan tepatnya di ITC Fatmawati.

Mekanisme penjualan yang ada di Toko Uj Outlet yaitu konsumen datang langsung ketoko dan memilih pakaian yang akan dibeli. Promosi yang dilakukan oleh Toko Uj Outlet masih kurang sehingga banyak konsumen yang belum mengetahui jika di Toko Uj Outlet menjual berbagai macam pakaian branded.

Atas dasar identifikasi masalah yang telah dipaparkan diatas, maka rumusan masalah pada penelitian ini adalah bagaimana membangun sebuah website penjualan untuk Toko Uj Outlet agar dapat mengembangkan bisnis usaha penjualan khususnya penjualan pakaian branded, serta mempermudah konsumen untuk mendapatkan informasi produk terbaru dan melakukan transaksi tanpa harus mengunjungi toko.

\section{METODE PENELITIAN}

\section{A. Metode Pengumpulan Data}

Metode pengumpulan data yang dilakukan oleh peneliti, sebagai berikut:

1. Metode Pengamatan

Penulis melakukan pengamatan secara langsung pada Toko Uj Outlet untuk mengetahui sistem penjualan pakaian yang dilakukan oleh Toko Uj Outlet.

2. Metode Wawancara

Selama penelitian untuk mendapatkan informasi secara lengkap maka penulis melakukan tanya jawab atau biasa disebut dengan wawancara kepada pemilik toko mengenai semua kegiatan yang berhubungan dengan sistem penjualan pakaian branded pada Toko Uj Outlet yang bertujuan untuk mendapatkan penjelasan lebih rinci dan jelas terkait dengan sistem penjualan pakaian branded yang berada pada Toko Uj Outlet.

3. Metode Studi Pustaka

Pada metode ini, penulis melakukan tinjauan pustaka yaitu dengan mencari sumber referensi yang berhubungan dengan permasalahan yang akan dibahas.

B. Metode Pengembangan Perangkat Lunak

Metode yang digunakan pada pengembangan perangkat lunak ini menggunakan model air terjun (waterfall model) yang terbagi memiliki tahapan-tahapan [2], yaitu:

1. Analisis Kebutuhan

Dalam tahapan ini, penulis melakukan pengamatan dan tanya jawab dengan pemilik toko untuk mengumpulkan data yang dibutuhkan dan mengetahui kendala yang terjadi pada sistem penjualan pakaian branded.

2. Desain 
Penulis melakukan penuangan pikiran dan perancangan sistem terhadap solusi dari permasalahan yang ada dengan menggunakan perangkat pemodelan sistem seperti diagram hubungan entitas (Entity Relationship Diagram) serta struktur navigasi.

3. Pembuatan Kode Program

Penulisan kode program atau coding merupakan penerjemah desain dalam bahasa yang bisa dikenali. Dalam tahap ini penulis merealisasikan perancangan sistem dengan memasukan kodingan dengan bahasa pemrograman PHP, HTML dan CSS.

4. Pengujian

Pada tahap ini, penulis melakukan pengujian terhadap kemampuan dan keefektifannya menggunakan Black Box Testing sehingga didapatkan kelemahan dan kekurangan sistem yang nantinya akan dilakukan pengkajian ulang.

5. Pendukung (support) atau pemeliharaan (maintenance) Dalam tahapan ini, sistem diinstal dan mulai digunakan. Selain itu juga memperbaiki error yang tidak ditemukan pada tahap pembuatan. Dalam tahap ini juga dilakukan pengembangan sistem seperti penambahan fitur dan fungsi baru.

\section{PEMBAHASAN}

\section{A. Analisa Kebutuhan Pengguna}

Pada website Toko Uj Outlet terdapat tiga pengguna yang dapat saling berinteraksi terdiri dari pengunjung, pelanggan, dan administrator. Kebutuhan dari masing-masing pengguna sebagai berikut:

\section{Halaman Pengunjung}

a. Pengunjung hanya dapat melihat produk-produk yang ditawarkan.

b. Pengunjung dapat melihat informasi detail setiap produk.

c. Pengunjung dapat melakukan pendaftaran pelanggan baru.

2. Halaman Pelanggan

a. Pelanggan dapat login dihalaman pengunjung.

b. Pelanggan dapat melihat-lihat produk yang ditawarkan.

c. Pelanggan dapat melihat informasi detail setiap produk dan bisa melakukan pembelian produk.

3. Halaman Administrator

a. Administrator dapat login ke halaman administrator.

b. Administrator dapat menambah, mengedit, dan menghapus kategori.

c. Administrator dapat menambah, mengedit, dan menghapus produk.

d. Administrator dapat menambah, mengedit, dan menghapus kota. e. Administrator dapat menambah administrator baru dan melihat data administrator.

f. Administrator dapat melihat data pelanggan.

g. Administrator dapat melihat detail setiap ada laporan pemesanan baru, mengirim pesanan pelanggan jika pelanggan sudah melakukan pembayaran serta menghapus pemesanan jika dalam 2 kali 24 jam pelanggan tidak melakukan pembayaran.

h. Administrator dapat melihat laporan pengiriman.

i. Administrator dapat melihat detail laporan penjualan.

j. Administrator dapat mengedit, blokir dan menghapus data administrator.

k. Administrator dapat mengunjungi website yang dibuat melalui ruang administrator.

1. Administrator dapat keluar dari halaman administrator.

B. Analisa Kebutuhan Sistem

Kebutuhan sistem pada website Toko Uj Outlet, antara lain:

1. Memberikan layanan untuk menampilkan produk-produk terbaru.

2. Menyediakan layanan transaksi penjualan.

3. Memberikan laporan transaksi penjualan.

4. Memberikan informasi tentang profil toko, cara berbelanja dan cara pembayaran.

5. Menyediakan layanan pendaftaran baru.

6. Memberikan layanan konfirmasi pembayaran.

7. Sistem secara otomatis dapat mengurangi stok pakaian pada saat terjadi transaksi penjualan pakaian.

C. Rancangan Antarmuka

Rancangan antar muka (interface) pada Sistem Penjualan Pakaian Berbasis Web pada Toko Uj Outlet, sebagai berikut:

1. Rancangan Halaman Login Administrator

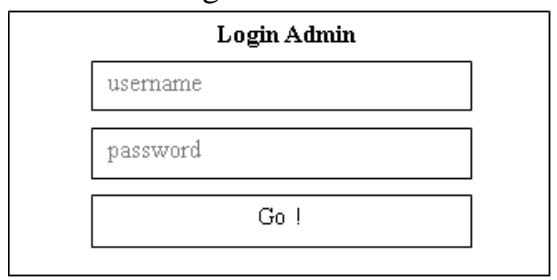

Gambar 1.

Rancangan Halaman Login Administrator

2. Rancangan Halaman Utama Administrator 


\begin{tabular}{|l|l|}
\hline Uj Outlet & [logout] \\
\hline \hline Beranda & \\
Pesanan Baru & Selamat Datang! \\
Pengiriman & HixxxxX, selamat datang di ruang Adminisitrator. \\
Penjualan & Silahkan pilih mernu untul mergelela konten diwebsite Uj \\
Produk & Outlet. \\
Kate gori & \\
Produk & \\
Kota & \\
Pengguna & \\
Tambah Admin & \\
Grup Admin & \\
& \\
& \\
\end{tabular}

Gambar 2.

Rancangan Halaman Utama Administrator

3. Rancangan Halaman Keranjang Belanja

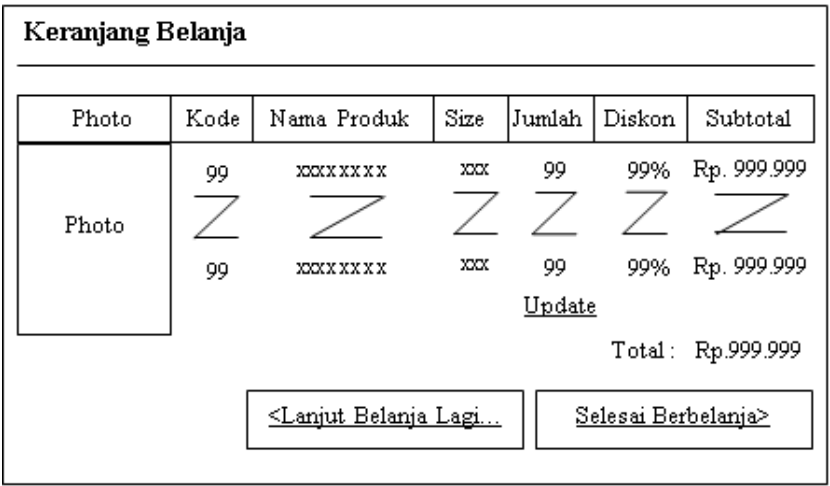

Gambar 3.

Rancangan Halaman Keranjang Belanja

4. Rancangan Halaman Alamat Pengiriman

\begin{tabular}{|c|c|c|c|c|c|c|}
\hline \multicolumn{7}{|c|}{ Alamat Pengiriman } \\
\hline \multirow{3}{*}{\multicolumn{2}{|c|}{$\begin{array}{l}\text { Nama Lengkap : } \\
\text { Alamat Lengkap } \\
\text { Telepon/Hp : }\end{array}$}} & \multicolumn{3}{|c|}{ 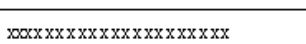 } & & \\
\hline & & \multicolumn{3}{|c|}{ 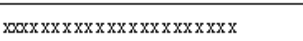 } & & \\
\hline & & \multicolumn{2}{|l|}{$2 x x x \times x \times x x$} & & & \\
\hline \multicolumn{2}{|l|}{ Email } & \multicolumn{3}{|c|}{ 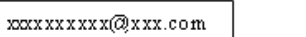 } & & \\
\hline \multirow{2}{*}{\multicolumn{2}{|c|}{$\begin{array}{l}\text { Kota Tujuan } \\
\text { Kode Pos : }\end{array}$}} & \multicolumn{2}{|c|}{--pilih kota-- } & & & \\
\hline & & $x 0 x x x$ & & & & \\
\hline gambar & Kode & \begin{tabular}{|l} 
Nama \\
produk
\end{tabular} & Size & jumlah & diskon & subtotal \\
\hline $\operatorname{coc} x \times x x$ & $\operatorname{xoxxx}$ & $\operatorname{xoxxxx\times x}$ & $x x x$ & 999 & $99 \%$ & 999.999 \\
\hline$<$ & 1 & $\gamma$ & 1 & 1 & $\angle$ & 1 \\
\hline$x 0 x \times x \times x$ & $x 0 x \times x$ & $\operatorname{xoxxxxxx}$ & $\operatorname{xoxx}$ & 999 & $99 \%$ & 999.999 \\
\hline & & & & & Total : & 999999 \\
\hline Kembal & & & & & & Proses \\
\hline
\end{tabular}

Gambar 4.

Rancangan Halaman Alamat Pengiriman

5. Rancangan Halaman Konfirmasi Pembayaran

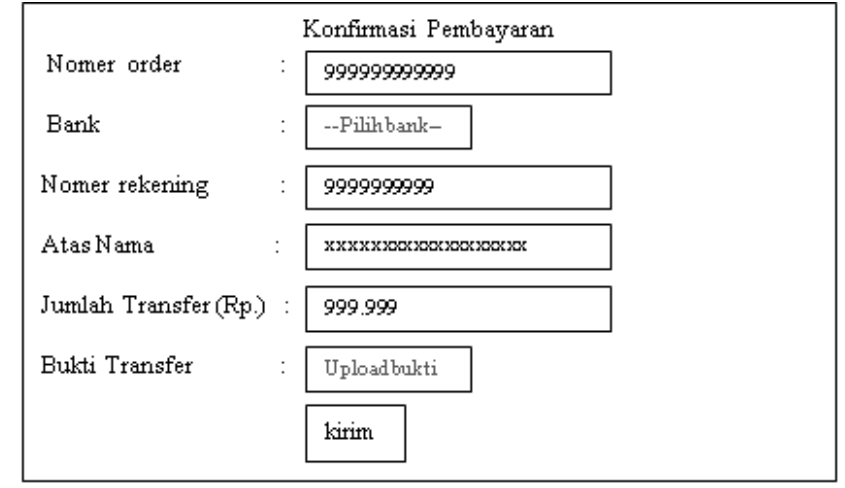

Gambar 5.

Rancangan Halaman Konfirmasi Pembayaran

\section{Entity Relationship Diagram}

Entity Relationship Diagram (ERD) merupakan diagram yang digunakan untuk merancang tabel-tabel yang nantinya akan diimplementasikan pada basis data [3].

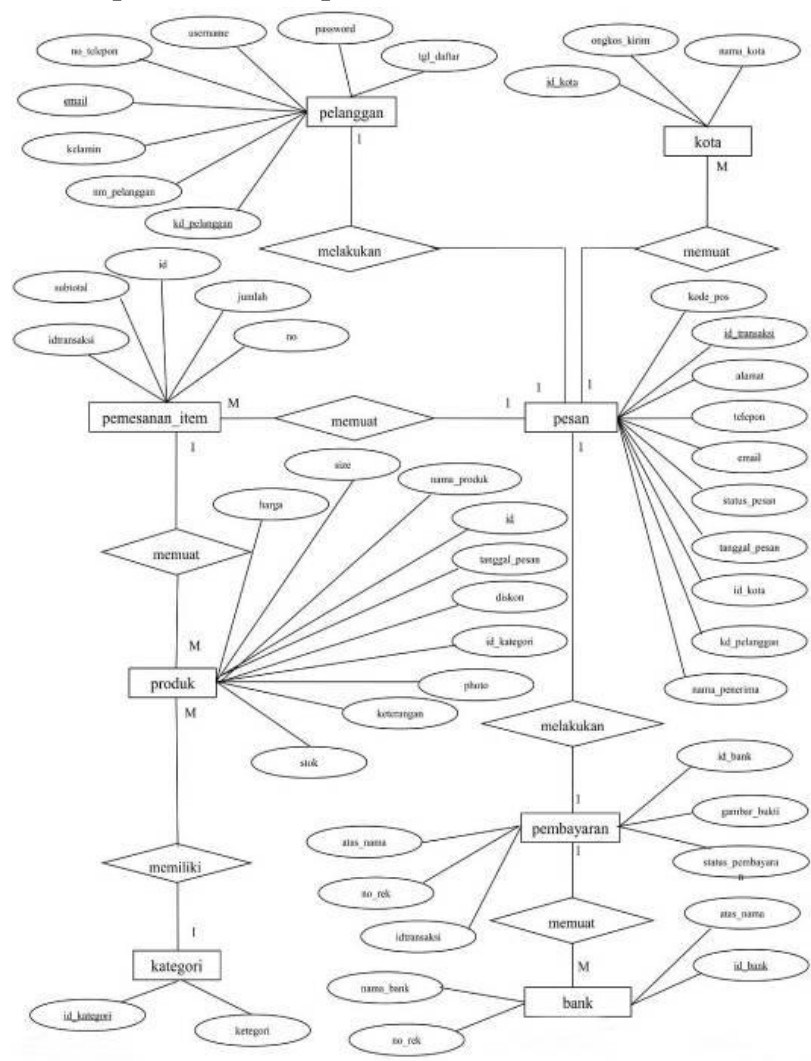

Gambar 6.

Entity Relationship Diagram

E. Rancangan Struktur Navigasi

Struktur navigasi adalah susunan menu atau hierarki dari suatu situs yang menggambarkan isi dari setiap halaman dan link atau navigasi tiap halaman pada suatu situs web [4]. 
1. Struktur Navigasi Halaman Pengunjung

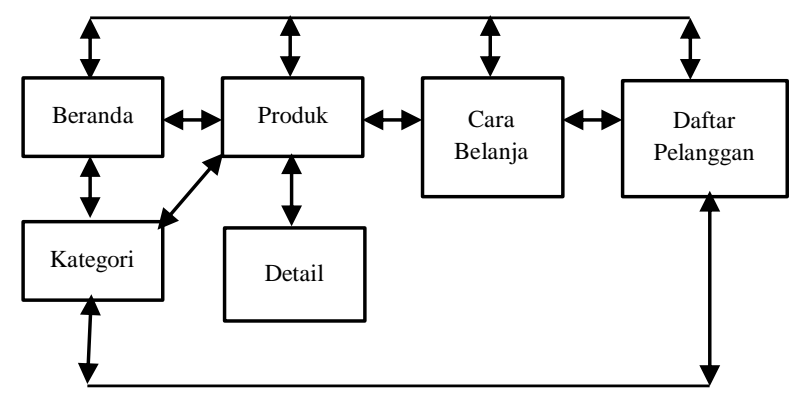

Gambar 7.

Struktur Navigasi Halaman Pengunjung

2. Struktur Navigasi Halaman Pelanggan

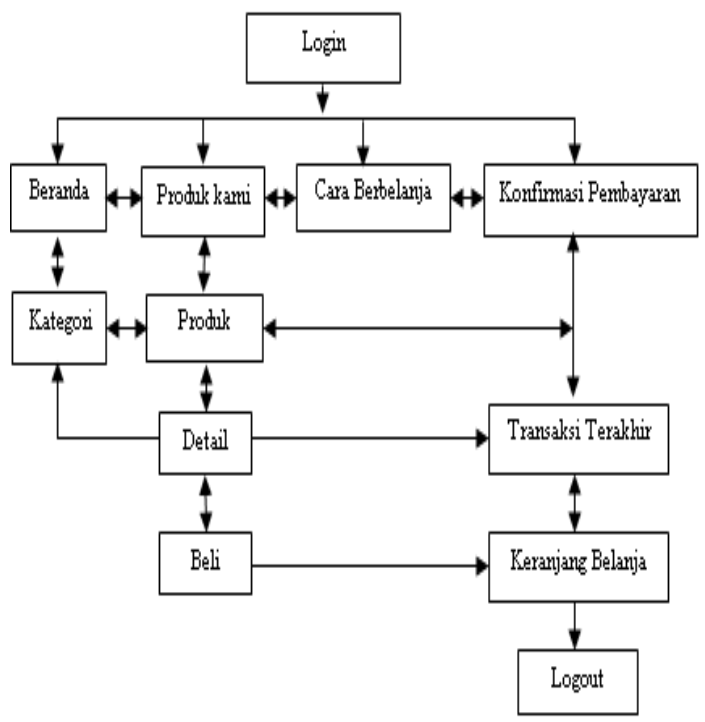

Gambar 8.

Struktur Navigasi Halaman Pelanggan

3. Struktur Navigasi Halaman Administrator

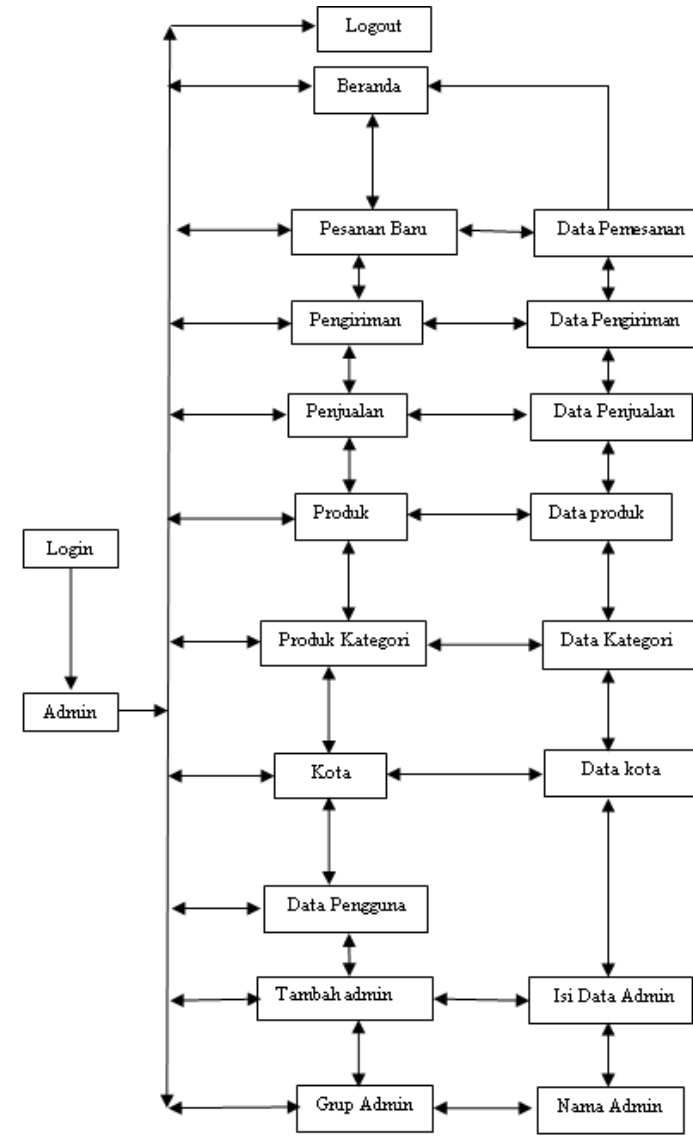

Gambar 9.

Struktur Navigasi Halaman Administrastor

F. Implementasi

1. Halaman Pendaftaran

Pada halaman ini, pengunjung dapat melakukan pendaftaran untuk melakukan transaksi pemesanan baju.

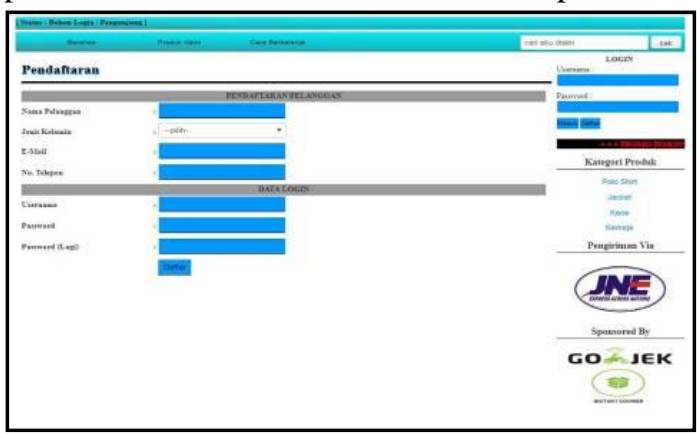

Gambar 10

Implementasi Halaman Pendaftaran Pelanggan

2. Halaman Utama Pengunjung

Pada halaman ini, pengunjung dapat melihat produk yang ditawarkan oleh Toko Uj Outlet. 
Jurnal SISFOKOM, Volume 07, Nomor 01, Maret 2018

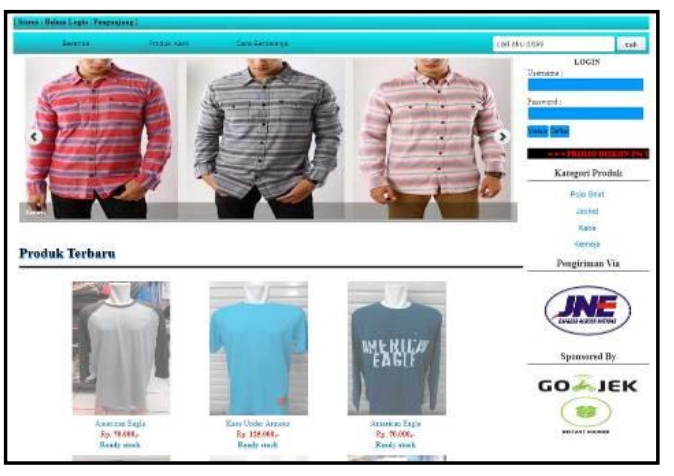

Gambar 11.

Implementasi Halaman Utama Pengunjung

3. Halaman Keranjang Belanja

Pada halaman keranjang belanja dapat menampilkan data produk yang dipesan oleh pelanggan.

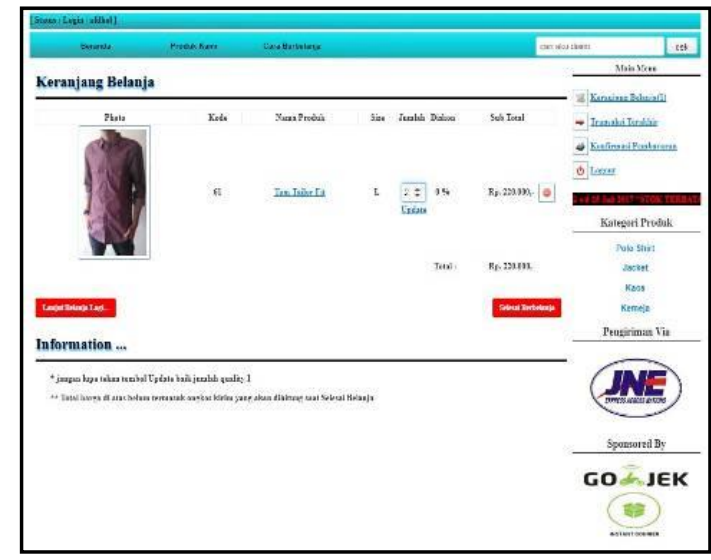

Gambar 12

Implementasi Halaman Keranjang Belanja

4. Halaman Alamat Pengirim

Pada halaman ini, pelanggan dapat menuliskan alamat untuk pengiriman pakaian yang dipesan.

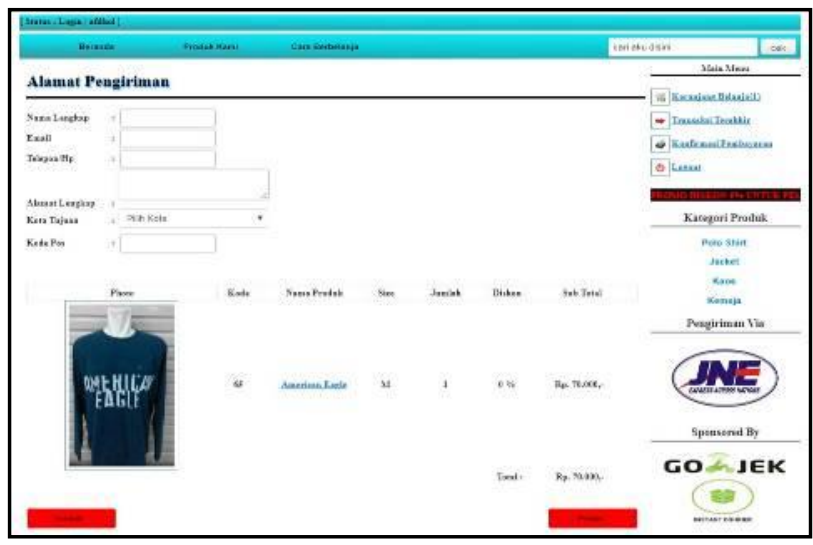

Gambar 13

Implementasi Halaman Alamat Pengiriman

5. Halaman Konfirmasi Pembayaran
Halaman ini berisi form untuk melakukan konfirmasi pembayaran yang telah dilakukan oleh pelanggan.

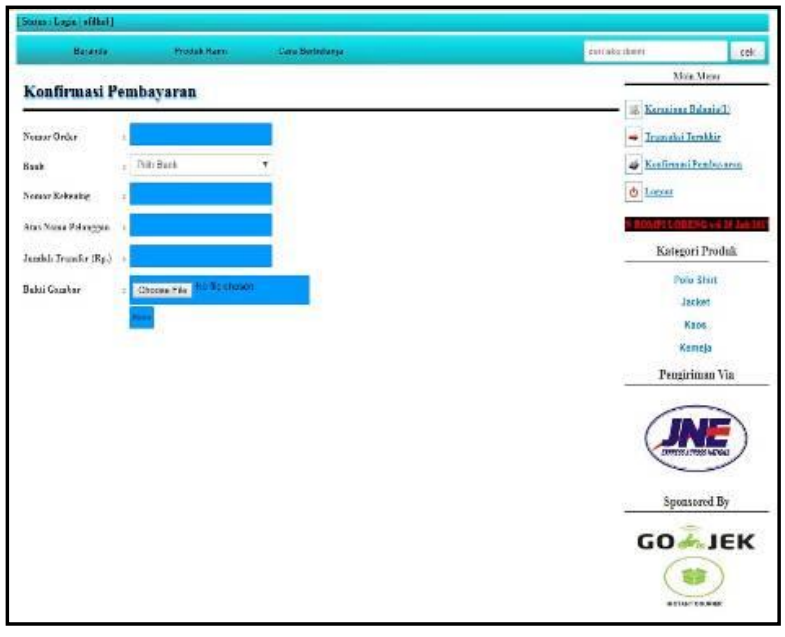

Gambar 14

Implementasi Halaman Konfirmasi Pembayaran

6. Halaman Login Administrator

Pada halaman login, administrator harus memasukkan username dan password supaya dapat mengelola data produk dan data penjualan.

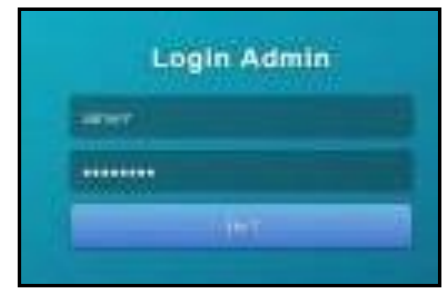

Gambar 15.

Implementasi Halaman Login Administrator

7. Halaman Produk Pada Administrator

Adminisrator dapat melihat data produk, menambahkan data produk, mengubah data produk dan menghapus data produk.

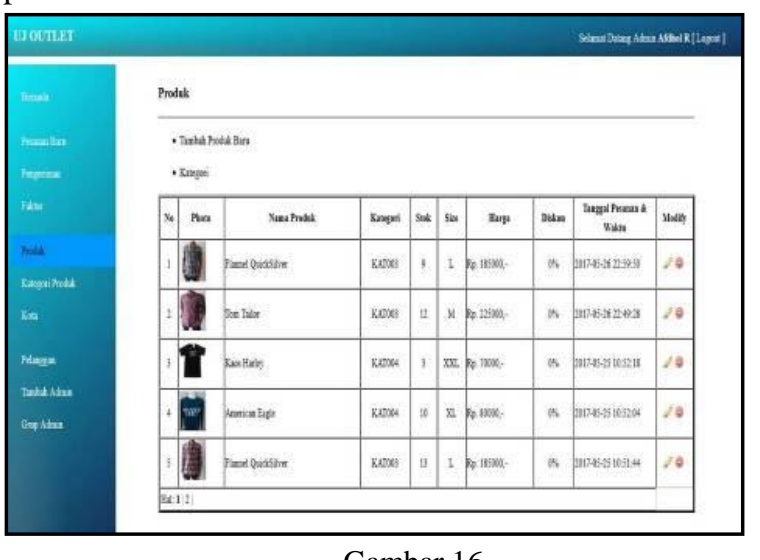

Implementasi Halaman Produk Pada Administrator 
8. Halaman Penjualan Pada Administrator

Pada halaman ini, administrator dapat melihat data penjualan yang ada di Toko Uj Outlet.

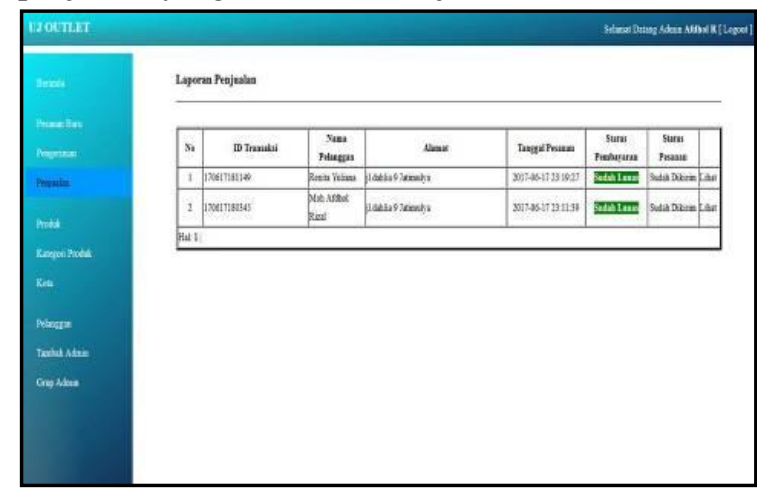

Gambar 16.

Implementasi Halaman Penjualan Pada Administrator

\section{G. Black Box Testing}

1. Pengujian Terhadap Login Admin

Tabel 1.

Pengujian Black Box Testing Halaman Login Admin

\begin{tabular}{|c|c|c|c|c|}
\hline No. & $\begin{array}{c}\text { Skenario } \\
\text { Pengujian }\end{array}$ & $\begin{array}{l}\text { Hasil yang } \\
\text { diharapkan }\end{array}$ & $\begin{array}{c}\text { Hasil } \\
\text { Pengujian }\end{array}$ & Kesimpulan \\
\hline 1 & $\begin{array}{l}\text { Mengkosongkan } \\
\text { semua isian data } \\
\text { Login, } \\
\text { kemudian tekan } \\
\text { "Login". }\end{array}$ & $\begin{array}{lr}\text { Sistem } & \text { akan } \\
\text { menolak } & \text { Akses } \\
\text { Login } & \text { dan } \\
\text { menampilkan } \\
\text { pesan " } & \text { Silahkan } \\
\text { isi } & \text { kolom } \\
\text { username } & \text { terlebih } \\
\text { dahulu”. } & \end{array}$ & $\begin{array}{l}\text { Sesuai } \\
\text { Harapan }\end{array}$ & Valid \\
\hline 2 & $\begin{array}{l}\text { Hanya mengisi } \\
\text { data username } \\
\text { dan } \\
\text { mengkosongkan } \\
\text { data password } \\
\text { dan data } \\
\text { kode,kemudian } \\
\text { tekan "Login". }\end{array}$ & $\begin{array}{lr}\text { Sistem } & \text { akan } \\
\text { menolak } & \text { akses } \\
\text { Login } & \text { dan } \\
\text { menampilkan } & \\
\text { pesan " Silahkan } \\
\text { isi } & \text { kolom } \\
\text { password dahulu”. }\end{array}$ & $\begin{array}{l}\text { Sesuai } \\
\text { Harapan }\end{array}$ & Valid \\
\hline 3 & $\begin{array}{l}\text { Hanya mengisi } \\
\text { data password } \\
\text { dan } \\
\text { mengkosongkan } \\
\text { data username } \\
\text { dan data kode, } \\
\text { kemudian tekan } \\
\text { "Login". }\end{array}$ & $\begin{array}{lr}\text { Sistem akan } \\
\text { menolak akses } \\
\text { Login dan } \\
\text { menampilkan } \\
\text { pesan “ Silahkan } \\
\text { isi kolom yang } \\
\text { kosong”. }\end{array}$ & $\begin{array}{l}\text { Sesuai } \\
\text { Harapan }\end{array}$ & Valid \\
\hline 4 & $\begin{array}{l}\text { Mengisikan data } \\
\text { Login yang } \\
\text { benar, kemudian } \\
\text { mengklik } \\
\text { tombol "Login". }\end{array}$ & $\begin{array}{l}\text { Sistem menerima } \\
\text { akses Login dan } \\
\text { kemudian } \\
\text { langsung } \\
\text { menampilkan } \\
\text { halaman admin }\end{array}$ & $\begin{array}{l}\text { Sesuai } \\
\text { Harapan }\end{array}$ & Valid \\
\hline 5 & \begin{tabular}{l}
\multicolumn{2}{l}{ Mengisikan data } \\
username yang \\
benar,lalu \\
mengisikan \\
password \\
dengan data \\
yang salah
\end{tabular} & $\begin{array}{lr}\text { Sistem } & \text { akan } \\
\text { menolak } & \text { akses } \\
\text { Login } & \end{array}$ & $\begin{array}{l}\text { Sesuai } \\
\text { Harapan }\end{array}$ & Valid \\
\hline
\end{tabular}

\begin{tabular}{|c|l|l|l|l|}
\hline & $\begin{array}{l}\text { kemudian } \\
\text { mengklik } \\
\text { tombol "Login". }\end{array}$ & & \\
\hline 6 & $\begin{array}{l}\text { Mengisikan data } \\
\text { username yang } \\
\text { salah, lalu } \\
\text { mengisikan } \\
\text { password } \\
\text { dengan data } \\
\text { yang benar } \\
\text { kemudian } \\
\text { mengklik } \\
\text { tombol "Login". }\end{array}$ & & Login & Valid \\
\hline 7 & $\begin{array}{l}\text { Mengisikan data } \\
\text { username } \\
\text { yangsalah,lalu } \\
\text { mengisikan } \\
\text { password dand } \\
\text { dengan data } \\
\text { yang salah } \\
\text { kemudian } \\
\text { mengklik } \\
\text { tombol "Login". }\end{array}$ & $\begin{array}{l}\text { Sistem agin } \\
\text { menolak akses }\end{array}$ & & \\
& & Harapan & \\
\end{tabular}

2. Pengujian Terhadap Halaman Keranjang Belanja

Tabel 2.

Pengujian Black Box Testing Halaman Keranjang Belanja

\begin{tabular}{|c|c|c|c|c|}
\hline No & $\begin{array}{l}\text { Skenario } \\
\text { Pengujian }\end{array}$ & $\begin{array}{l}\text { Hasil yang } \\
\text { diharapkan }\end{array}$ & $\begin{array}{c}\text { Hasil } \\
\text { Pengujian }\end{array}$ & Kesimpulan \\
\hline 1 & $\begin{array}{l}\text { Jumlah dipilih } \\
\text { kurang dari } 1 \\
\text { kemudian klik } \\
\text { tombol } \\
\text { "Update" }\end{array}$ & $\begin{array}{l}\text { Sistem akan } \\
\text { menolak dan } \\
\text { menampilkan } \\
\text { jumlah } \\
\text { belanjaan } \\
\text { kosong }\end{array}$ & Sesuai Harapan & Valid \\
\hline 2 & $\begin{array}{l}\text { Jumlah yang } \\
\text { dipilih melibih } \\
\text { stok kemudian } \\
\text { klik tombol } \\
\text { "Update". }\end{array}$ & $\begin{array}{l}\text { Sistem akan } \\
\text { menolak dan } \\
\text { menampilkan } \\
\text { jumlah } \\
\text { belanjaan } \\
\text { kosong }\end{array}$ & Sesuai Harapan & Valid \\
\hline 3 & $\begin{array}{l}\text { klik tombol } \\
\text { "Delete". }\end{array}$ & $\begin{array}{l}\text { Sistem akan } \\
\text { menerima akses } \\
\text { hapus dan } \\
\text { kemudian } \\
\text { keranjang } \\
\text { belanja terhapus }\end{array}$ & Sesuai Harapan & Valid \\
\hline 4 & $\begin{array}{l}\text { klik tombol } \\
\text { "Lanjut } \\
\text { Belanja Lagi". }\end{array}$ & $\begin{array}{l}\text { Sistem } \\
\text { menerima akses } \\
\text { lanjut belanja } \\
\text { lagi dan } \\
\text { kemudian } \\
\text { menampilkan } \\
\text { halaman semua } \\
\text { produk }\end{array}$ & Sesuai Harapan & Valid \\
\hline 5 & $\begin{array}{l}\text { klik tombol } \\
\text { "Selesai } \\
\text { Berbelanja". }\end{array}$ & $\begin{array}{l}\text { Sistem } \\
\text { menerima akses } \\
\text { selesai belanja } \\
\text { dan kemudian } \\
\text { menampilkan } \\
\text { halaman alamat } \\
\text { pengiriman }\end{array}$ & Sesuai Harapan & Valid \\
\hline
\end{tabular}




\section{KESIMPULAN}

Kesimpulan dai penelitian ini adalah:

1. Pembuatan website penjualan pada Toko Uj Outlet ini dapat dijadikan sebagai media promosi bagi Toko Uj Outlet untuk memperluas jangkauan pemasaran.

2. Website penjualan pada Toko Uj Outlet dapat meningkatkan citra perusahaan.

3. Melalui website penjualan pada Toko Uj Outlet, pengunjung dapat mengetahui macam-macam produk pakaian bermerek terbaru dan dapat melakukan transaksi penjualan dengan konsumen tanpa harus mengunjungi toko secara langsung.

\section{REFERENSI}

[1] Kurnia, Jaya. 2016. Pengertian Penjualan Menurut Para Ahli Terbaru. Diambil dari: http://pengayaan.com/pengertian-penjualan-menurutpara-ahli-terbaru. (23 Agustus 2016).

[2] Sukamto, Rosa Ariani dan M. Shalahuddin. 2013. Rekayasa Perangkat Lunak Terstruktur dan Berorientasi Objek. Bandung : Informatika Bandung.

[3] Sulianta, Feri dan Fajri Rakhmat Umbara. 2015. Teknik Hebat Merancang Aplikasi Instan dan Berkualitas. Jakarta: PT Elex Media Komputindo.

[4] Binanto, Iwan. 2010. Multimedia Digital Dasar Teori Dan Pengembangan. Yogyakarta : Andi Publisher. 